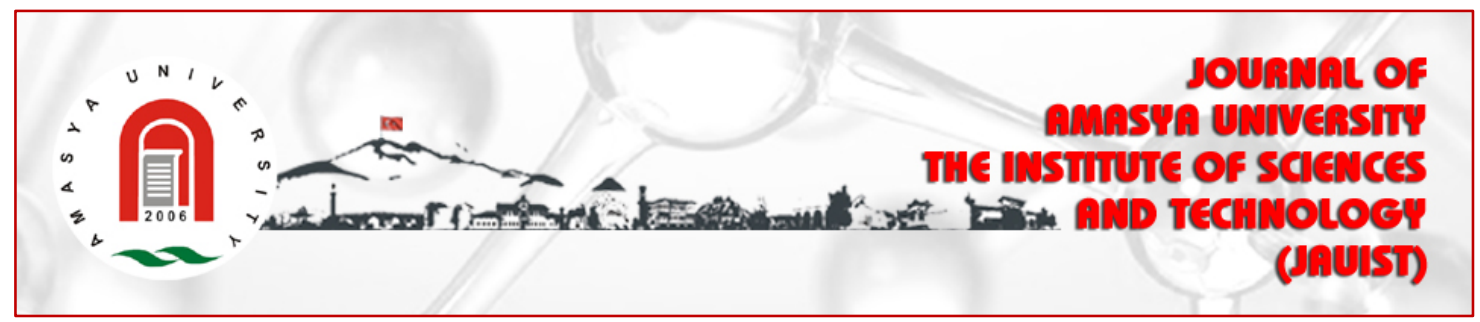

\title{
INVESTIGATION OF STRUCTURAL PROPERTIES OF ZnS AND Mo-DOPED ZnS NANOPARTICLES ANNEALED IN $\mathrm{H}_{2} S$ MEDIUM
}

\section{1Ömer ŞAHİN1, 2Sabit HOROZ2 ${ }^{2}{ }^{* 3}$ Arzu EKINCİ}

${ }^{1}$ Siirt University, Faculty of Engineering, Department of Chemical Engineering,

Siirt, Turkey, 56100

2 Siirt University, Faculty of Engineering, Department of Electrical and

Electronics Engineering, Siirt, Turkey, 56100

${ }^{*}$ Department of Occupational Health and Safety, Siirt School of Health, Siirt

University, Siirt, Turkey, 56100

ORCID*3: ID/0000-0002-2951-9557

Research Type: Original Research Article

Received: 08.11.2021, Accepted: 28.12.2021

*Corresponding author: aekinci80@siirt.edu.tr

https://doi.org/10.54559/jauist.1020502

\section{Abstract}

In this study, the structural properties of Mo-doped ZnS nanoparticles (NPs), which were synthesized at room temperature using the successive ionic layer adsorption and reaction (SILAR) method and annealed in $\mathrm{H}_{2} \mathrm{~S}$ gas for 1 hour at $550{ }^{\circ} \mathrm{C}$, were investigated. The XRD result shows that ZnS and Mo Doped ZnS NPs are in lattice cubic structure. The average crystal size of NPs was calculated using the Debye - Scherrer formula. The crystal size of the pure ZnS NPs varied with doping. The average crystalline size of $\mathrm{ZnS}$ and Mo- doped $\mathrm{ZnS}$ NPs were found as $5.5 \mathrm{~nm}$ nd $4.3 \mathrm{~nm}$, respectively.

Key Words: Annealing, doping, nanoparticles, structural. 


\section{Özet}

$\mathrm{Bu}$ çalışmada, ardışık iyonik tabaka adsorpsiyon ve reaksiyon (SILAR) yöntemi ile oda sıcaklığında sentezlenen ve $550{ }^{\circ} \mathrm{C}^{\prime}$ de $\mathrm{H}_{2} \mathrm{~S}$ gazında 1 saat tavlanan Mo-katkılı ZnS nanoparçacıklarının (NP'ler) yapısal özellikleri incelenmiştir. XRD sonucu, ZnS ve Mo Katkılı ZnS NP'lerin kafes kübik yapıda olduğunu göstermektedir. NP'lerin ortalama kristal boyutu, Debye-Scherrer formülü kullanılarak hesaplandı. Saf ZnS NP'lerin kristal boyutu, doping ile değiști. ZnS ve Modifiye ZnS NP'lerin ortalama kristal boyutu sırasıyla $5.5 \mathrm{~nm}$ ve $4.3 \mathrm{~nm}$ olarak bulundu.

Anahtar Kelimeler: Tavlama, doping, nanopartiküller, yapısal.

\section{Introduction}

In semiconductor nanoparticle systems, the energy from the sun is directly converted into electrical energy. This phenomenon is called the photovoltaic effect. Semiconductor solar systems maintain their durability longer and do not require frequent maintenance like condensing systems The fact that The lower production costs and the fact that they do not need much budget for post-installation processes make the use of semiconductor nanoparticles in solar energy systems more advantageous than others. Basically used photovoltaic films are II-VI group compounds (CdS, CdS, ZnS, CdTe, ZnSe etc.), III-V group compounds or IV-VI group compounds, as well as some organic materials. [1].

II-VI compounds are ionic and covalently bonded [2]. Although II-VI group semiconductor compounds crystallize both in cubic form and in hexagonal form [3], they are generally in cubic form at room temperature. Some of the II-VI group semiconductors such as CdS, Cu(In, Ga) and CdTe with an optical band gap of $2.4 \mathrm{eV}$ play an important role as the glass material of basic solar cells. $\mathrm{Cd}$ has toxic properties in terms of industrial production and environmental pollution.A non-toxic material should replace CdS as the window material of solar cells. With a wide optical band gap of 3.2-3.8 eV, $\mathrm{ZnS}$ is a potential candidate to replace toxic CdS [4]. The band gap is the energy required for electrons to go into the excited state. Theoretically, smallsized dots show a larger band gap than similar clusters. It requires energy equal to or higher than its bandgap energy to enter an excited state [5-7]. ZnS nanoparticles (NPs) are a good host 
material because of their wide band gap semiconductor material and energy band characteristic [8]. Doping is an effective method to tune the energy level surface states of ZnS NPs. Different types of doping at different concentrations have been used to improve the characterization and optical properties of ZnS NPs [9-11].

The Mo-doped inducible bandgap gap of ZnS NPs can be used to achieve a wider optical spectrum response of optoelectronic devices. It has also been reported that molybdenum (Mo) atoms can change the band structures of semiconductors [12]. The behavior of these NPs differs from bulk semiconductors due to the increase in particle size, changes in band structure, increase in band gap and division of the edges of the band into discrete energy levels [13]. As it is known, there are many methods to produce doped and undoped semiconductor nanoparticle thin films. Among these methods, successive ionic layer adsorption and reaction (SILAR) [14] The SILAR method stands out due to some advantages such as being inexpensive, simple, easy to apply, not requiring vacuum, and easy control of growth parameters. Therefore, in this study, we performed the annealing process in H2S gas atmosphere after Mo-doped ZnS NPs were synthesized by SILAR method at room temperature. The effect of both $\mathrm{H}_{2} \mathrm{~S}$ gas and Mo doping on the structural properties of ZnS NPs was investigated.

\section{Experimental Part}

The synthesis of undoped and Mo-doped ZnS NPs was synthesized using sequential ionic layer adsorption and reaction (SILAR) method at room temperature. Zinc acetate Sodium sulfide and ammonium molybdenum tetrahydrate were used as $\mathrm{Zn}, \mathrm{S}$ and Mo ion sources, respectively. In this study, $1.75 \mathrm{~g}$ of zinc acetate and $0.62 \mathrm{~g}$ of sodium sulfide were prepared separately in 80 $\mathrm{mL}$ of distilled water solution for $\mathrm{ZnS}$ and Mo-doped $\mathrm{ZnS}$. For the synthesis of Mo-doped ZnS NPs, 3\% ammonium molybdenum tetrahydrate was mixed into an aqueous solution of zinc acetate. All films were obtained on glass substrates. Before deposition, glass substrates were cleaned in acetone and then in distilled water for 10 minutes. Then, the obtained pure $\mathrm{ZnS}$ and Mo-doped $\mathrm{ZnS}$ thin films were annealed at $550{ }^{\circ} \mathrm{C}$ for 1 hour in $\mathrm{H}_{2} \mathrm{~S}$ gas.

$\mathrm{X}$-ray diffraction (XRD) measurements were made to determine the crystalline forms and phases of the films obtained. These measurements were made by X-ray diffractometry using CuK $\alpha$ beam at $\lambda=1541 \AA$ A wavelength. 


\section{Results and Discussion}

The observed peaks in the XRD spectrum reveal the crystal structure of the material. Also, XRD analysis is used to estimate the particle size in the structure. The XRD spectra of undoped and Mo-doped ZnS NPs annealed in an $\mathrm{H}_{2} \mathrm{~S}$ gas atmosphere are shown in Figure 1. As seen in Figure 1, XRD models of the films were obtained in the range of $20^{\circ} \leq \theta \leq 70^{\circ}$. It has been observed that the films have a polycrystalline structure. It relates to the lattice planes (111), (220) and (311) corresponding to the standard ICDD data showing the cubic zinc mixture structure. As seen in Figure 1, the preferred orientation of the films is along the (111) direction.

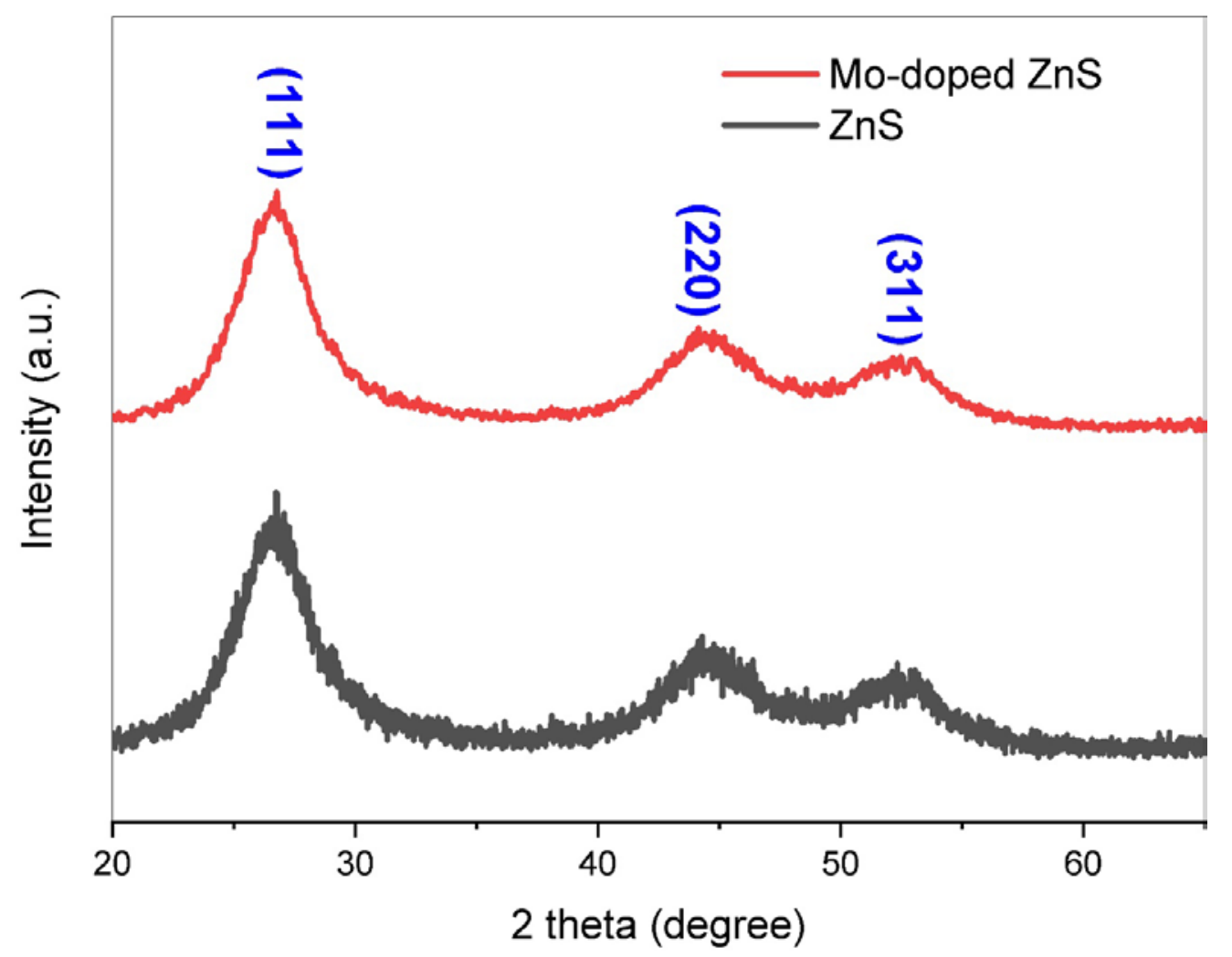

Figure 1. XRD patterns of ZnS and Mo-doped ZnS NPS.

The absence of characteristic peaks of the doped Mo metal indicates that a homogeneous structure was obtained $[9,13]$. The structure of ZnS NPs is almost unchanged by Mo doping, but there is broadening at the tops of the peaks. This broadening at the tops of the peaks indicates the formation of ZnS NPs. 
The observed intensity of the XRD peaks of Mo-doped ZnS NPs decreased with Mo doping. This is evidence of reduced crystallinity in nanoparticles [15]. Also, since the ionic radius of $\mathrm{Mo}^{+6}(0.065 \mathrm{~nm})$ is smaller than the ionic radius of $\mathrm{Zn}^{2+}(0.074 \mathrm{~nm})$, it may cause a stress in the lattice [16].

The crystallite sizes of undoped and doped ZnS NPs were calculated as $5 \mathrm{~nm}$ nd $4.3 \mathrm{~nm}$, respectively using the Debey-Scherrer equation.

$$
t=0.9 \lambda /(\beta \cos \theta)
$$

where $t$ is the average size of the NPs, $\lambda$ is the wavelength of the $x$-ray, $\beta$ is the full width at half height in radians (FWHM), and $\theta$ is the Bragg's diffraction angle

\section{Conclsuion}

In the present study, ZnS and Mo-doped ZnS NPs synthesized by SILAR technique were annealed at $550{ }^{\circ} \mathrm{C}$ for 1 hour in the presence of $\mathrm{H}_{2} \mathrm{~S}$ gas. As a result of the annealing process, it was determined that both thin films were cubic, but the crystallite size of Mo-doped $\mathrm{ZnS}$ (4.3 $\mathrm{nm}$ ) was lower than that of $\mathrm{ZnS}(5 \mathrm{~nm})$ due to the Mo-doped metal.

As a result of the present study, it has been clearly observed that the additive metal is an important parameter in the adjustment of the crystallite size.

\section{References}

1. Kisslinger R., Hua W., Shankar K. 2017. Bulk heterojunction solar cells based on blends of conjugated polymers with II-VI and IV-VI inorganic semiconductor quantum dots, Polymers, 9 (2):35-63.

2. Tongay S., Durgun E., Ciraci S. 2004. Atomic strings of group IV, III-V, and II-VI elements, Applied Physics Letters, 85(25):6179-6181.

3. Chalana S.R., Bose R.J., Krishnan R.R., Kavitha V.S., Sreedharan R.S., Mahadevan Pillai V.P. 2016. Structural phase modification in $\mathrm{Cu}$ incorporated nanostructured zinc sulfide thin films, Journal of Physics and Chemistry of Solids, 95 (8): 24-36.

4. Serrano J., Cantarero A., Cardona M., Garro N., Lauck R., Tallman R.E., Ritter T.M., Weinstein B.A. 2004. Raman scattering in ZnS, Physical Review B, 69 (14) 014301-014312. 
5. Kamat, P.V.,Christians, J.A., Radich, J.G. 2014. Quantum dot solar cells: hole transfer as a limiting factor in boosting the photoconversion efficiency. Langmuir, 30(20):5716- 5725.

6. Chang, J.-Y., Su, L.-F., Li, C.-H., Chang, C.-C., Lin, J.-M. 2012. Efficient "green" quantum dotsensitized solar cells based on $\mathrm{Cu}_{2} S$-CuInS$S_{2}-\mathrm{ZnSe}$ architecture, Chemical Communications, 48(40): 4848-4850.

7. Hod, I.,Zaban, A. 2014. Materials and Interfaces in Quantum Dot Sensitized Solar Cells: Challenges, Advances and Prospects Langmuir, 30(25), 7264-7273.

8. Jabeen U., Adhikari T., Shah S.M., Pathak D., Wagner T., J Nunzi.-M. 2017. Influence of. the dopant concentration on structural, optical and photovoltaic properties of Cu-. doped $\mathrm{ZnS}$ nanocrystals based bulk heterojunction hybrid solar cells, The European Physical Journal Applied Physics, 78 (3):34811-34816

9. Li Y., Zapien J., Shan Y., Liu Y., Lee S. 2006. Manganese doping and optical properties of ZnS nanoribbons by post annealing, Applied Physics Letters,88 (1) 013115.

10. Peng W., Cong G., Qu S., Wang Z. 2006. Synthesis and photoluminescence of ZnS: $\mathrm{Cu}$ nanoparticles, Optical Materials, $\mid 29$ (3) 313-317.

11. Pal M., Mathews N., Morales E.R., Jimenez J.G., Mathew X. 2013. Synthesis of Eu+doped ZnS nanoparticles by a wet chemical route and its characterization. Opt. Mater. 35 (14) 26642669.

12. Naz H., Nauman A. R., Zhu X., Xiang B. 2018. Effect of Mo and Ti doping concentration on the structural and optical properties of ZnS nanoparticles, Physica E: Low-dimensional Systems and Nanostructures, 100 (6) 1-6

13. Mote V. D., Purushotham Y., Dole B. N. 2013. Structural, morphological and optical properties of Mn doped ZnS nanocrystals, Ceramica, 59 (3) 395-400.

14. Dhawale D.S.,Dubal D.P., Phadatare M.R., Patil J.S.,Lokhande C., (2011). Synthesis and characterizations of CdS nanorods by SILAR method: effect of film thickness, Journal of Materials Science, 46(14):5009-5015.

15. Saikia D., Raland R., Borah J. 2016. Influence of Fe doping on the structural, optical and. magnetic properties of $\mathrm{ZnS}$ diluted magnetic semiconductor, Physica. E, Low-dimensional Systems \& Nanostructures, 83 (4) 56-63.

16. Khalkhali M., Liu Q.X., Zeng H.B., Zhang H. 2015. A size-dependent structural evolution of ZnS nanoparticles, Scientific Reports, 5 (1) 14267-14283. 